\title{
Pomoc wykluczonych, czyli o daremności - Zagłada w śladach Ludwika Heringa
}

\author{
The excluded help, or about futility - the Holocaust \\ in Ludwik Hering's Traces
}

\author{
Beata Przymuszała \\ Uniwersytet im. Adama Mickiewicza w Poznaniu \\ IORCID: 0000-0002-8915-748X
}

\begin{abstract}
The article shows the manner of presenting the Holocaust in Ludwik Hering's stories. It focuses on the construction of the narrator and the protagonist, analyzing their attitude to the situation of Jews. In the context of the anti-Semitism mentioned in the texts, the protagonists not only distance themselves from it, but they try to help the Jews. However, they are also aware of the limited nature of this help for Jews and reveal its realities. A helping Pole, who is socially excluded, is aware of the power of social rules which destroy the help itself.
\end{abstract}

Key words: Holocaust, the ghetto, helping Jews, empathy

Streszczenie: Artykuł pokazuje sposób przedstawiania Zagłady w opowiadaniach Ludwika Heringa. Skupia się na konstrukcji narratora i bohatera, analizując ich stosunek do sytuacji Żydów. W kontekście przywoływanego w tekstach antysemityzmu protagoniści nie tylko się wobec niego dystansują, ale starają się pomóc Żydom. Zdają sobie jednak przy tym sprawę z ograniczonego charakteru tej pomocy, odsłaniają jej realia. Pomagający Polak, sam społecznie wykluczony, ma świadomość siły społecznych reguł, które samą pomoc niszczą.

Słowa kluczowe: Zagłada, getto, pomoc Żydom, empatia

Książka Heringa to szczególna pozycja wśród tekstów o Zagładzie. Przede wszystkim wymownajestjej długotrwała nieobecność w polskiej świadomości: składające się na nią opowiadania ukazały się w 1945 i 1946 roku w „Kuźnicy” i w „Głosie Ludu”. Spośród trzech z nich jedno, zatytułowane Ślady, wkrótce przedrukowano w zbiorze $W$ oczach pisarzy. Wybór opowieści wojennych (1939-1945) - opracowanym przez Herlinga-Grudzińskiego (Rzym 1947), fragmenty tego utworu pojawiły się też w Wypisach szkolnych dla klasy VIII szkoły podstawowej (Warszawa 1947). Natomiast opowiadanie zatytułowane Meta było publikowane tylko we fragmentach: czytelnicy czasopism mogli poznać jedynie wybór z części pierwszej oraz całą ostatnią, 
piątą część. Całość Mety ukazała się po raz pierwszy w 2011 roku (Hering 2011 , 103). Trzecie z opowiadań, zatytułowane Zieleniak, jest poświęcone sytuacji ludności w czasie powstania warszawskiego i z uwagi na tematykę nie będzie przedmiotem niniejszego artykułu.

I w Śladach, i w Mecie niezwykłym wyzwaniem jest postać narratora towarzyszącego wydarzeniom/uczestniczącego w nich - na jakiej zasadzie buduje on opowieść?

Obecne w szkolnych wypisach Ślady są historią małego chłopca, szmuglującego jedzenie do getta, poczuwającego się do odpowiedzialności za matkę. Tekst został tak skonstruowany, by po obrazie małych szmuglerów („Tak w mieście wołano za nimi: „Kot!...Kot!...,” i to znaczyło tyle co "Jude”. Zlepki błota i strachu. Zatajony w mroku sens nadchodzącego dnia: żebrzące, szczute dzieci", (Hering 2011, 20)) przybliżyć perspektywę jednego z nich: chłopiec opowiada o głodzie, o płaczu i bezsilności matki, o swoim strachu przed leżącymi na ulicach trupami, o tym, jak sobie próbuje radzić z okradającymi szmuglerów „łobuzami”, o pomocy, jakiej raz doznał od nieznajomego mężczyzny (który umył go, nakarmił i pozwolił się wyspać w łóżku) i o swoim ogromnym zmęczeniu. Zakończenie opowiadania to opis wielkiej likwidacji w 1942 roku, skupiony na następującej scenie: oddzielona od dziecka matka idzie - poganiana przez Niemca - tyłem, nie mogąc oderwać od malucha wzroku. Ostatnie zdania tekstu brzmią tak:

Przestrzeń - zraniona spojrzeniem matki oderwanej od dziecka - nie krwawi.

Pada drobny, gęsty śnieg. Niebo, ziemia i zrównane z ziemią getto drżą jak druk na rozsypującej się karcie (Hering 2011, 29).

Nie sposób wykluczyć, iż matka żegnała się wzrokiem z poznanym wcześniej przez czytelników chłopcem, zarazem kimkolwiek nie byłoby dziecko, dotkliwość opowiadania dla odbiorców pozostanie mocnym doświadczeniem. Autorowi udało się - dzięki oddaniu głosu jednemu ze szmuglujących dzieci - wywołać u czytających ten tekst poczucie „zaniku obcości”, jednocześnie wzbudzając poczucie bezsilności. Krajobraz po likwidacji getta pozostaje przestrzenią geograficzną - ale jest to przestrzeń martwa. „Przestrzeń, która nie krwawi” - ta animizacja/personifikacja nie służy jedynie zaprzeczeniu wzniosłości, równie dobrze może wiązać się z martwotą, niemotą, brakiem czucia - zmrożeniem. Pozostaje poza dostępnymi słowami („rozsypujący się druk”).

Sylwia Karolak pokazywała, które fragmenty tego opowiadania zostały pominięte $\mathrm{w}$ wypisach (przedstawiające drastyczne realia życia w getcie oraz sformułowania uderzające w Polaków ${ }^{1}$ ). Zarazem badaczka podkreśla, iż nawet w tak skróconej wersji obecność tego tekstu mogłaby kształtować inny sposób myślenia o Zagładzie, ponieważ okrojony utwór:

\footnotetext{
${ }^{1}$ „Przypuszczać można, iż fragmenty dotyczące krzywd, jakich żydowskie dzieci doświadczały od swych „aryjskich rówieśników”, (...) pominięte zostały ze względu na ich oceniającą wymowę, krytyczną wobec polskiego - „aryjskiego” społeczeństwa. (...) Inne usunięto prawdopodobnie z powodu ich drastyczności (...) lub po to, by nie budować przekonującego obrazu tragedii Żydów, który mógłby dodatkowo wzmocnić siłę oskarżenia Polaków" (Karolak 2014, 128).
} 
Mógł stać się zaczątkiem kanonu literatury Zagłady - jest pierwszym tekstem, jaki pojawia się na liście lektur, w którym głos oddany zostaje ofierze, żydowskiemu dziecku czy też dzieciom. (...) Dopiero Ślady uświadamiają koszty strategii artystycznej wybranej przez Tadeusza Borowskiego i Zofię Nałkowską - wyboru opcji obiektywizmu (utracenie perspektywy ofiar, niepokazywanie cierpienia i strachu) oraz reporterskiego dystansu powstałego wskutek lektury dokumentów (dystans wobec grozy, brak ocen; dokumenty mają „przemówić same”). Hering natomiast, przyjmując postawę empatyczną, utożsamia się z żydowskim strachem, poniżeniem, nie tylko współodczuwa, ale i współcierpi - tym samym znosi dystans (Karolak 2014, 131-132).

Oddanie głosu dziecku, „obrysowanie getta” jego spojrzeniem i doznaniami pomaga $\mathrm{z}$ pewnością w podjęciu wysiłku empatii, uwiarygadniając opis (dziecko jest w tym przypadku relacjonującym to, co widzi, jako „oczywiste”: wskazując na różnice między tamtym a tym światem, na tych różnicach poprzestaje) - nie jest jednak w żadnym wypadku prostym „współczującym gestem”, nie ma ułatwiać emocjonalnej identyfikacji ${ }^{2}$. Narrator niemal nie komentuje wypowiedzi chłopca (choć ważna, niezwykle uderzająca jest delikatność, z jaką przybliża jego wygląd), posługuje się mową niezależną, z wyjątkiem stwierdzenia: „Nie ma wątpliwości w niczym, co mówi. Jeśli nawet nie akceptuje - to na pewno się nie dziwi” (Hering 2011, 23). To uważne słuchanie chłopca, powaga, jaką zostaje obdarzony, świadczą o narratorskiej sylwetce, o jego stosunku do codzienności dokonującej się na jego oczach Zagłady. To słuchanie nie zostaje bez śladu - ma rację Sylwia Karolak, pisząc o współcierpieniu: słuchanie sprawia ból, bo nie pozwala zapomnieć o tym, co dzieje się ludziom żyjącym obok i każe pamiętać o niewystarczalności podejmowanych działań, o ich absolutnej nieadekwatności.

W posłowiu do pierwszego książkowego wydania całych opowiadań Heringa Ludmiła Murawska-Péju pisze o swym wuju:

Ludwik, bez skóry, nieodporny na cudzy ból, ból wszystkich istnień zdolnych do cierpienia. Wymagający, bezwzględny wobec siebie, gotów płacić najwyższą cenę, która jest ceną życia, angażuje się w pomoc uciekinierom zza muru getta ${ }^{3}$.

Nie tylko więc empatia, która nie należała do częstych reakcji (eufemistycznie to ujmując), ale i realnie świadczona pomoc Żydom współtworzą obraz autora/narratora tych opowiadań. Obraz empatycznego świadka?

Adam Lipszyc w świetnej, niezwykle zniuansowanej, interpretacji sylwetki Ludwika Heringa skupia się na jednym z opisanych przez niego obrazów z getta (opisanych w liście do Józefa Czapskiego i obecnym w opowiadaniu zatytułowanym Meta). Autor Śladów wspomina sytuację, w której przeprowadził wzrokiem (sygnalizując konieczność schowania się) Żydówkę przez zagrażający jej teren. Kiedy to wreszcie się udało, kobieta

${ }^{2}$ Odwołuję się w tym miejscu do sporu o różnicę między współczuciem a empatią - zob. Krawczyńska D., 2004, Empatia? Substytucja? Identyfikacja? Jak czytać teksty o Zagładzie?; Tokarska-Bakir J., 2004, Kontekst ocalenia. O empatii i żałobie w historii, literaturoznawstwie i gdzie indziej, „Teksty Drugie”, nr 5.

${ }^{3}$ Murawska-Péju L., Posłowie, w: Hering L., 2011, Ślady, s. 110. 
niezdarnie go pocałowała, mówiąc: „spotkałam człowieka”. Hering ujmuje to następująco:

I tak już jesteśmy związani jakby jedną liną nad przepaścią (właśnie tak) przez klika godzin. Na mój znak zaczyna iść w moim kierunku i na mój znak cofa się. (...) Ta „wiążąca linia" to bardziej pogrubienie słowne niż metafora. (...) I to tylko po to to wszystko napisałem, żebyś wiedział, że wstyd, rozpacz, kłamstwo, kłamstwo tamtej chwili pali mnie tak samo dziś, jak i wtedy. Bo przecież to był moment odcięcia liny od siebie. A to mnie hamowało w pisaniu, że pisząc klaruje, jaki jestem nie dość, że szlachetny, to jeszcze cierpiący (Czapski, Hering 2017, 288).

Lipszyc dostrzega w tych słowach przerażenie wywołane poczuciem, iż robiąc "tak niewiele” (z czego wiele jest skazane i tak na porażkę), można choćby przez moment siebie docenić - fałszując ówczesną rzeczywistość:

Hering trwa w pozycji człowieka niosącego pomoc ludziom wydanym na pastwę morderczego okrucieństwa, człowieka, który rzuca im linę spojrzenia, zawsze jednak w końcu musi ją odciąć, nigdy nie może być z nimi do końca. A ponieważ wie, że jego pomoc nigdy nie jest dostateczna i nigdy nie może naprawdę uchronić innego przed machinami zła, wstydzi się, że sam mógłby zostać wzięty za kogoś, kto podtrzymuje fikcję o człowieku - i że jego słowa, choćby najokrutniejsze i najbardziej połamane, mogłyby zakryć grozę i wieczną niedostateczność niesionej pomocy (Lipszyc 2018, 202).

Hering nie chce być uznany za wspierającego świadka.

$\mathrm{W}$ opowiadaniach posługuje się figurą narratora zdystansowanego - jest wprawdzie obok bohaterów, w opisach nie posuwa się jednak dalej niż ironia mu na to pozwoli, słucha i przekazuje to, co usłyszał, ale bez dopowiedzeń.

Nie sposób wykluczyć, że to on sam pozwolił chłopcu z przywoływanego już opowiadania przenocować u siebie, nakarmił go i umył. Jak wspomina tamto spotkanie dziecko:

Ja mu powiedziałem, że myślałem, że on jest niedobry człowiek. To on się tak zdziwił, aż się zaczerwienił: „Naprawdę tak myślałeś, naprawdę?”, i mówi: „To pewnie tak jest". Ale to nieprawda - on jest na pewno dobry (Hering 2011, 26).

Zaczerwienienie wskazuje na pojawienie się silnych emocji - jakby dziecko dotknęło obolałego miejsca. Między wstydem (że robię tak niewiele) i poczuciem winy (że nie mogę pomóc) „ja” obnaża nie tyle swoją niedoskonałość, ile poczucie własnej niegodności/splamienia - wrażenie, że jest się „niedobrym człowiekiem”. Mocno to eksponuje: osoba, która wydawała się spełniać wszystkie kryteria zaangażowania w pomoc Żydom, przyjmuje za własne określenie deprecjonujące jej człowieczeństwo. Próbując pomagać, dostrzega zarówno niewystarczalność tej pomocy, jak i niejednoznaczność własnej sytuacji. Przecież może pomagać, bo jest usytuowany na „lepszej pozycji”. On nie ma problemu z chodzeniem po ulicach, nie został oznaczony, nie boi się własnej twarzy (co było efektem napiętnowania tzw. złego (żydowskiego) wyglądu). 
Opowiadający „wstydząc się” gestu pomocy, nie chce, by mógł on „zasługiwać na wdzięczność”. Narrator opowiadań cofa się przed próbami podziękowania za pomoc, nie tylko dlatego, że jest to pomoc zawsze niewystarczająca. Ta wdzięczność dowartościowuje osobę ją świadczącą (wywyższa ją), będąc jednocześnie sygnałem, płynącym od skazanych na zagładę, że dokonał się w nich proces interioryzacji naznaczenia: każdy gest przeciwstawiający się temu traktują jak wyjątek od reguły. Wdzięczność za drobny gest pomocy jest przecież nieadekwatna (jak ten niezdarny pocałunek kobiety „przeprowadzonej spojrzeniem” przez ulicę).

Pomoc Żydom w opowiadaniach Heringa odwołuje się do obrazu „ja” osoby ją „świadczącej” - jest rozpięta między wstydem z powodu jej niewystarczalności a lękiem przed jej dowartościowującym wymiarem. Jakby narrator pytał - czy można nie pomóc, będąc w lepszej sytuacji? Akceptując zarazem swą uprzywilejowaną pozycję (nawet jeśli jest ona lepsza jedynie relatywnie)? Pytanie to - choć wydaje się naiwne w swym absolutystycznym wymogu - problematyzuje „jasną stronę" pomocy i jest zadawane z pozycji osoby, której wiedza o okolicznościach jej świadczenia do naiwnych nie może należeć. Pomoc wydaje się tak bardzo niewystarczająca, że sama chęć jej udzielenia sprawia wrażenie minimalnego etycznego gestu, który i tak zawsze jednak może wzmacniać „ja” pomagających.

W Śladach narrator pozostawiał czytelniczki i czytelników z obrazem pustej przestrzeni po getcie, poprzedzonym opisem patrzącej za własnym dzieckiem Żydówki - spojrzeniem, które miało zachować jej dziecko w pamięci, nie służyło ratowaniu, nie mogło już dziecku pomóc. To spojrzenie było bezsilne - mimo że miało moc „zranienia przestrzeni”. Było spojrzeniem, które wołało o życie, zdając sobie sprawę z daremności:

Ta kobieta szła tyłem - patrząc na dziecko. Potknęła się, upadła. Kopnięta przez Niemca zgarnęła się z ziemi i szła dalej, tyłem, w rytm kroku pędzonego oddziału, nie odrywając oczu od bramy. Sto kroków - potem mur skręca (Hering 2011, 28).

Zestawienie tych dwóch spojrzeń jest niewspółmierne, tak jak niewspółmierna była sytuacja ludzi funkcjonujących po dwóch stronach muru. W Mecie - opowiadaniu, które po wojnie ukazało się jedynie we fragmentach - część nieopublikowana skupia się na reakcjach polskiego społeczeństwa na Zagładę: reakcjach przede wszystkim (choć nie tylko) tej „lepszej”, wykształconej grupy, odsłaniając zarazem los osoby, która zdecydowała się pomagać Żydom w przechodzeniu na drugą stronę.

W badaniach nad literaturą, która krótko po wojnie próbuje zdawać sprawę z doświadczeń zagładowych, opowiadania Heringa czytane są przede wszystkim jako relacje obrazujące skalę polskiego antysemityzmu. Katarzyna Chmielewska podkreśla, iż w tych tekstach ma on bardzo szeroki zasięg, żadna z grup nie jest go pozbawiona, a przy jednoczesnym procederze szmuglowania przez mur i dorabiania się na nim i czerpania w ten sposób zysku przez polską stronę pozwala on stać się postawą osłaniającą 
faktyczne polskie motywacje ${ }^{4}$. Bożena Keff podkreśla absolutnie negatywny wymiar opowieści o stosunku Polaków wobec Zagłady:

W opowiadaniach Heringa nikt nie wypowiada pod adresem Żydów choćby jednej uwagi, która włączałaby ich w obręb gatunku ludzkiego. Żaden powszechny ludzki odruch nie jest w ich wypadku ani ludzki, ani oczywisty, włączając odruch samozachowawczy. Niemniej, żeby nic nie czuć, trzeba zrobić pewien wysiłek. „Chwilami zapominam, że to są Żydzi, i to jest jednak straszne" - mówi jedna z pań goszczących u inżyniera (Keff 2020, 29).

Przywołana wypowiedź zostaje szybko - u Heringa - odparta łagodnym wyrzutem, że nas Polaków niszczy sentymentalizm - a stawiający tę tezę podkreśla, iż jeśli pozbędziemy się tej wady: „Docenimy to jako rozwiązanie kwestii, której sami, przez sentymentalizm właśnie, nie potrafiliśmy w porę i... obawiam się... nie potrafilibyśmy nigdy rozwiązać" (Hering 2011, 82). Jak zauważa Keff, jedyny ślad odmowy takiego myślenia pojawi się $\mathrm{w}$ nieporęcznie sformułowanych zdaniach „babki od kóz”, która mówi, że „nawet najgorszy robak, też przecież chce żyć" (Hering 2011, 89) -

Wodziła wkoło białymi oczami, szukając potwierdzenia, ale ludzie nie zwracali na nią uwagi, rozchodzili się do mieszkań, i stara stała z rozłożonymi rękami - niepewna: dziwić się czy nie dziwić, że Żydzi chcą żyć (Hering 2011, 89).

Ostry sarkazm wydaje się wyrazem rozpaczy, przejścia przez nieprzekraczalną granicę. Bożena Keff, w podobnym tonie komentując te słowa, pisze o „za daleko posuniętym uniwersalizmie” kobiety pilnującej kozy i dodaje: >>Poza tym babka jest „nikim” $<<$ (Keff 2020, 29).

Cudzysłów eksponuje chwiejną perspektywę klasyfikacji - „babka jest nikim" w społecznej hierarchii, nie ma de facto głosu, mówi, jakby nie mówiła. Ale jednak mówi, przynajmniej się odważa - kobieta porównująca Żydów do robaków odwraca sens antysemickich haseł (rozpropagowanych przez niemiecką propagandę w ostrzeżeniach zrównujących Żydów z insektami) i uderza w etykę, uzasadniającą panowanie nad zwierzętami. I ta wypowiedź, wypowiedź „z dołu”, zmienia perspektywę patrzenia na dziejącą się na oczach Polaków Zagładę.

Nieopublikowane w czasopismach części Mety zawierają przytoczone mocne antysemickie wypowiedzi (jak i te słowa starszej kobiety próbującej zrozumieć, co Żydzi czują) - ale nie ten ich aspekt wyróżnia pominięcie środkowej partii opowiadania (choć jego natężenie z pewnością nie było bez znaczenia). Istotnym elementem środkowych części jest historia

\footnotetext{
${ }^{4}$ „Hering nie pozwala zamknąć rozpoznania antysemickiej mowy w klasowym rozróżnieniu, które znamy jako dyskurs o zdrowym centrum i chorym marginesie (...). Poczucie dystansu, niedostępności i izolacji getta, figura bystandera nie mają nic wspólnego z opisem połączonych krwioobiegów gospodarczych i społecznych, z figurą polskiego beneficjenta Zagłady, którą znajdziemy u Heringa" - Chmielewska K., 2019, Narracje alternatywne wobec polityki pamięci. Lata czterdzieste, w: Opowieść o niewinności. Kategoria świadka Zagłady w kulturze polskiej (1942-2015), Hopfinger M., Żukowski T. (red.), s. 120, 122. Zob. też: Janicka E., Świadkowie własnej sprawy. Polska narracja dominujaca wobec Zagłady na przykładzie teksu Marii Kann Na oczach świata (1943), w: Lata czterdzieste. Początki polskiej narracji o Zagładzie, 2019, Hopfinger M., Żukowski T. (red.), Warszawa. (Janicka podkreśla, iż Hering pokazał: „Skalę jednokierunkowego transferu ruchomości i nieruchomości, który dla Żydów oznaczał walkę o życie, a dla Polaków interes" - s. 136).
} 
Brzozowskiego, stróża w garbarni. To historia wykluczenia - jednej z wersji polskich losów. Między pierwszą częścią Mety, skupioną na zarysowaniu relacji handlowych między dwiema stronami muru, z dokładnym wskazaniem polskich reakcji („Każda prawie rodzina po aryjskiej stronie była dotknięta nieszczęściem i żałobą i to było niewątpliwie zbrodnią Hitlera - ale jeśli chodziło o Żydów, Hitler był tylko wykonawcą wyroku boskiego" (Hering 2011, 51), a ostatnią częścią, w której pomoc jednemu z Żydów przez Brzozowskiego kończy się (po przypadkowym odnalezieniu uszykowanej przez stróża kryjówki) wydaniem młodego mężczyzny w ręce Niemców, zawarty jest życiorys człowieka, który po przyjeździe do miasta za pracą został człowiekiem bez miejsca.

Wykonując najcięższą i wyniszczającą pracę w garbarni, Brzozowski był zawsze „nie swoim”: „ - Ot, cham - mówiono. - Dorwał się jak głupi do roboty, zbija kabzę na morgi. Ciągnie do gnoju...” (Hering 2011, 56). Mimo determinacji powodującej, iż w tych warunkach zaczyna sobie układać życie, zakłada rodzinę, zaczyna lepiej zarabiać, los mu nie sprzyja - wypadek przy pracy powoduje utratę sił i konieczność przejścia na mniej intratne miejsce. Reakcje ludzi obok niego pracujących nie są mu obojętne - można powiedzieć, że jest on osobą świadomą „swojego miejsca w tych relacjach", mocno je przeżywającą:

Brzozowski miał otwarte oczy na te różnice. Sam zepchnięty za ostatnie sztachety jak chore bydlę, myślał często w długie noce o fabrycznej, miejskiej i ludzkiej sprawiedliwości. Marzył o powrocie na ziemię, gdzie znów poczułby się człowiekiem (Hering 2011, 62).

Odsunięty, zepchnięty, wciąż funkcjonujący nawet nie tyle „na poboczu”, ile poza grupą robotnik „komplikuje sobie” sytuację jeszcze mocniej, rozpoczynając dodatkową pracę w żydowskiej firmie, by móc m.in. opłacić szkołe jedynemu, późno urodzonemu synowi. Staje się „żydowskim parobkiem" -

Brzozowki nie przejął się tym - do społeczności miejskiej i tak nie należał. Na zawsze pozostał „chamem”, „ćwokiem” i „cieciem”. Żył w odosobnieniu i może dlatego zaraził się przekonaniami masy. (...)

Obca była Brzozowskiemu ich mowa, obce obrzędy kiwających się w bożnicach postaci w białych z czarnymi pasami opończach - ale zrozumiała aż nadto cała reszta codziennego życia (Hering 2011, 69).

Funkcjonowanie poza grupą może się wiązać (i pewnie często się wiąże) z mniejszą podatnością na grupowe przekonania, ale brak wrogości wobec Żydów uzasadnia mocniej poczucie wspólnej biedy ${ }^{5}$, codzienne przebywanie obok siebie. Syn Brzozowskiego wychowuje się razem z dziećmi

${ }^{5}$ Jak komentuje narrator: „Tak było u wielu - u wszystkich prawie. Tak było i u najbliższego sąsiada, szmaciarza Majeranca, którego mijał o świcie, wracając z fabryki, i mijał wieczorem wracającego $\mathrm{z}$ twarzą tak wynędzniałą, że z przodu widać było tylko oczy, a z boku nos.

Owszem, obserwował dwa świetnie prosperujące sklepy Hasfelda, ale nie dziwiło go to więcej niż wspaniałe sklepy zamożnych chrześcijan, a daleko mniej niż bogactwo fabrykanta i jego syna, raz po raz zmieniającego kształt i kolor auta" (Hering 2011, 70). 
żydowskich robotników i różnica między nimi nie byłaby dla bohatera Mety ważna, gdyby nie „przypadkowa” śmierć ukochanego chłopaka - już studenta, który ginie razem ze swym żydowskim kolegą, zamordowany „jak Żyd” przez bojówki endeckie. „Nie byłaby ważna”, ale jednak na „różnicę” zwraca uwagę jego żona, matka zamordowanego chłopaka, mówiąc do matki drugiego z zabitych: „- Mietek... no, ale... za co mój?” (Hering 2011, 73). Tych słów, które jak oskarżenie z ust kogoś bliskiego odebrała Żydówka, Brzozowski nie komentuje. Reaguje dopiero, gdy przychodzą do nich przedstawiciele endeków, chcąc przeprosić za pomyłkę („a właściwie nie od nas zależny wypadek w akcji" - Hering 2011, 74) i zwrócić koszty pogrzebu. Brzozowski wyrzuca ich, a o jego emocjonalnym stanie najlepiej świadczy to, że tej nocy - będąc w pracy - jest bliski popełnienia samobójstwa.

Jego historia nie jest bez znaczenia dla podejmowanych przez niego w czasie wojny decyzji. Z jednej strony świadomość, że nie udało mu się uratować młodego Żyda, któremu chciał pomóc w ucieczce z getta, przypomina mu o śmierci syna, zwiększając dotkliwość porażki (jakby kolejny raz nie mógł zapobiec śmierci tych, którzy mu ufali). Ale z drugiej strony, ten osobisty aspekt wydaje się jeszcze bardziej pogłębiony, nie sprowadza się tylko do powrotu traumy (co w żadnym wypadku nie osłabia siły jej ponownego doświadczania). Brzozowski rozumie siłę wykluczenia, ponieważ miażdżyła ona jego życie: ulokowany na samym dnie, nie mógł na nic liczyć, nie powinien niczego się spodziewać. Mógł jedynie trwać w miejscu wyznaczonym przez społeczność, do której przybył. I pewnie by tak trwał - gdyby nie zobaczył, jakie są dalsze możliwe etapy procesu odrzucania: śmierć syna, który ginie jako Żyd, odsłania meritum wykluczania. Przemoc, która nie cofnie się przed eliminacją.

Brzozowski zna wykluczenie, podobnie jak „babka od kóz”, która porównując broniących się Żydów do robaków, zwraca uwagę na zwierzęcy, podstawowy odruch obronny, na instynkt życia. To bolesny, dojmujący paradoks: figura dehumanizacji Żydów staje się w wypowiedzi tej kobiety wyrazem ostrego sprzeciwu wobec pokrętnych wywodów, uzasadniających możliwość eliminacji - czyli zabijania. Wypowiedź kobiety pokazuje nie tylko, że nie wolno sprowadzać Żydów do roli zwierząt, ale - więcej - że nie wolno zabijać nawet zwierząt najniższych. Ich pragnienie życia jest niezbywalne. Jakby nieświadomie przejmując sposób myślenia nazistów, dokonuje jego całkowitego przeformułowania przez zaprzeczenie założeniom.

I „babka od kóz”, i Brzozowski są „chamami” - nikt nie liczy się z ich zdaniem, nikt o to zdanie nie pyta. Gdy stróż przychodzi do dyrektora garbarni, by powiedzieć, że odchodzi z pracy, dyrektor odsyła go do kasy, nie pytając o powody.

Silne deprecjonowanie osób przez grupę sprzyja z pewnością działaniom o charakterze odwetowym - im bardziej ktoś czuje się zdegradowany, tym mocniej pragnie „odzyskać” poczucie wartości nierzadko kosztem „innych innych". Antysemickie poglądy (mocno eksponowane w opowiadaniach 
Heringa) mogłyby być w takim przypadku wyrazem „odwetu słabszych”. Psychologowie społeczni zauważają jednak, iż:

różne formy zagrożenia pozytywnego obrazu grupy własnej skutkują wzrostem negatywności postaw wobec „obcych”, chociaż efekt taki występuje przede wszystkim u osób silnie identyfikujących się z grupą własną (Kofta, Bilewicz 2011, 11).

Gdyby powyższe spostrzeżenia potraktować jako kontekst przybliżający sposób myślenia Brzozowskiego, to uwaga narratora o „osobnym życiu” protagonisty opowiadania pozwalałaby potraktować „brak zarażenia przekonaniami masy” jako wyraz „zbawiennego dystansu”. Można także byłoby spojrzeć na decyzję stróża z jeszcze innej strony, skupiając się na kwestii obrazu jego „ja”. Mowa tu - za psychologami - o różnicy w deprecjonowaniu innych wynikającej z posiadania niskiej lub wysokiej samooceny. Paradoksalnie bowiem, to osoby mające wysoką samoocenę najczęściej mocno reagują na jej obniżenie i chętniej podejmują stereotypy grupowe (Kofta, Bilewicz 2011, 12). Brzozowski z pewnością nie posiadał zbyt wysokiej samooceny, byłby to więc kolejny argument wyjaśniający (a przynajmniej próbujący naświetlić) jego decyzję.

Czy Brzozowski pomaga Żydom, bo był wcześniej wyśmiewany, poniżany, bo nie miał zbyt dobrego zdania o sobie? To wiele przybliża, ale nie pozwala zapomnieć o innych, którzy tak nie robili (którzy antysemityzmem odreagowywali swoje poczucie upokorzenia). Bohater opowiadania na końcu, gdy odchodzi z pracy, mówi dyrektorowi o dziurze, która umożliwiała Żydom przedostawanie się na drugą stronę muru i każe ją zamurować. Tę scenę Adam Lipszyc komentuje następująco: „W obliczu niemal nieuchronnej śmierci, która czeka na zbiegów także poza murami getta, aktem miłosierdzia okazuje się ostatecznie odcięcie drogi ucieczki i zdławienie nadziei w środku" (Lipszyc 2018, 194). Lipszyc ma rację, używając pozornie jedynie nieadekwatnego określenia: miłosierna może być odmowa „wzmacniania złudzeń”. Ale też nie sposób nie zauważyć, iż Brzozowski decyduje się na ten akt z trudem, po wielu próbach przeciwstawienia się antysemickim działaniom po tej stronie muru:

Stary jakby nie słyszał - szedł wolno do wyjścia - w połowie Sali zadreptał ciężko w miejscu - odwróciwszy się trochę, zachrypiał:

- Za kominem... w starym fundamencie.... Jest dziura. - Zachłysnął się. Szczęki kłębiły przez chwilę napływ śliny. Splunął na błyszczącą posadzkę i wywarczał głucho w stronę biurka: - Trzeba zamurować (Hering 2011, 101).

Działa, mając dotkliwą świadomość rozpoznania niemożności zmiany, taką świadomość, jaką dała mu próba wydobycia się ze swojego miejsca, ze swojego „społecznego dołu”: nie zmieni się świata. To świadomość rozpaczy, doświadczenia niemożności i ciemności. Jeśli, jak mówiła „babka od kóz", każdy robak chce żyć, to każdy wciąż trafia na przedstawiciela silniejszego gatunku. 
Gest Brzozowskiego jest mocną diagnozą przedwojennej i wojennej rzeczywistości: to nie tylko lęk wobec bycia uznanym za (niesłusznie, jego zdaniem) wspierającego świadka (zawsze pomagającego za mało), to także wyraz utraty wiary w możliwość zmiany tego świata. Świata, w którym nawet pomoc okazuje się przedłużaniem cierpienia.

Pytany niedawno o to, „jak uczyć o Zagładzie”, Jacek Leociak powiedział:

Uczę od dwudziestu pięciu lat i uważam, że bardzo trudno znaleźć język mówienia o Zagładzie. To nie była sytuacja, w której biedni Żydzi zostali zamordowani przez bardzo złych Niemców. Ta sytuacja wikła nas samych w mrok tego, do czego człowiek jest zdolny. Nie chodzi o to, żeby prezentować schemat historyczny. Raczej o to, żeby zadawać pytania i pokazywać innym tajemnicę, głębię ludzkiego znieprawienia, ale i niejednoznaczność tej sytuacji ${ }^{6}$.

Teksty Ludwika Heringa pozwalają w taki właśnie sposób myśleć o Zagładzie, prowokują do zadawania pytań bardzo trudnych, niemal bolesnych, na które nie ma i nie będzie „jasnych” odpowiedzi.

\section{Bibliografia:}

Czapski Józef, Hering Ludwik, 2017, Listy 1939-1982, t. II, Gdańsk.

Hering Ludwik, 2011, Ślady, Warszawa.

Karolak Sylwia, 2014, Doświadczenie Zagłady w literaturze polskiej 1947-1991. Kanon, który nie powstat, Poznań.

Keff Bożena, 2020, Strażnicy fatum. Literatura dekad powojennych o Zagładzie, Polakach i Żydach. Dyskurs publiczny wobec antysemityzmu, Warszawa.

Kofta Mirosław, Bilewicz Michał, 2011, Wprowadzenie. Zagrożenie psychologiczne a stosunki międzygrupowe: nowe idee, w: Kofta M., Bilewicz M. (red.), Wobec obcych. Zagrożenia psychologiczne a stosunki międzygrupowe, Warszawa.

Krawczyńska Dorota, 2004, Empatia? Substytucja? Identyfikacja? Jak czytać teksty o Zagładzie? „Teksty Drugie”, nr 5.

Lipszyc Adam, 2018, Ludwik Hering: racja milczenia, w: Czerwone listy. Eseje frankistowskie o literaturze polskiej, Kraków.

Światło w ciemności świeci. Rozmowa z Jackiem Leociakiem, 2018, „Krytyka Polityczna", nr 46.

Tokarska-Bakir Joanna, 2004, Kontekst ocalenia. O empatii i żałobie w historii, literaturoznawstwie i gdzie indziej, „Teksty Drugie”, nr 5. 115.

${ }^{6}$ Światło w ciemności świeci. Rozmowa z Jackiem Leociakiem, 2018, „Krytyka Polityczna”, nr 46, 
Pomoc wykluczonych, czyli o daremności - Zagłada w Śladach Ludwika Heringa

\section{O Autorce:}

Beata Przymuszała, dr hab., profesorka UAM - Zakład Semiotyki Literatury, literaturoznawczyni, teoretyczka, badaczka literatury XX i XXI wieku. Zajmuje się literaturą Zagłady, afektywnymi i emocjonalnymi aspektami tekstów, relacjami między tekstami kultury. Ostatnio opublikowała m.in.: Smugi Zagłady. Emocjonalne i konwencjonalne aspekty tekstów ofiar i ich dzieci (2016); Smugi Zagłady - książki przeoczone. Borwicz i inni (2019). 
